Filip E. Czaja

\title{
Między naturą a konwencją. Problem nazewnictwa w dialogu sokratycznym
}

Odpowiednie dać rzeczy słowo!

C. Norwid

I

Platon jest dla humanistyki postacią szczególną - „otworzył przed człowiekiem nowe, fascynujące i ciaggle nieogarnięte obszary doświadczenia"1. Jak zauważył Hegel, działalność ateńskiego myśliciela miała charakter przełomowy i stanowi istotną cezurę - wraz z nią filozofia stała się nauką ${ }^{2}$.

Zadziwiać może wielowymiarowość refleksji Platona, obejmującej liczne przedmioty oraz rozległe obszary, od ontologii do teorii państwowości. Koncepcje Arystoklesa wpłynęły na rozmaite dziedziny nauki, dla przykładu na matematykę ${ }^{3}$. Natomiast platońską filozofię idei uznaję - w duchu heglowskim - za pomost spajający myśl

1 R. Legutko, Wstę, w: E. Voegelin, Platon, tłum. A. Legutko-Dybowska, Warszawa 2009, s. 16.

2 G.W.F. Hegel, Wyktady z historii filozofii, thum. Ś.F. Nowicki, t. 2, Warszawa 1996, s. 3.

3 „Platonizm matematyczny okazuje się wewnętrznym problemem w matematyce i jest źródłem jej rozwoju" (Z. Król, Platon i podstawy matematyki współczesnej. Pojęcie liczby u Platona, Nowa Wieś 2005, s. 7). 
starożytną z nowoczesnymi koncepcjami, a wśród nich ze strukturalną teorią opozycji langue i parole Ferdinanda de Saussure'a ${ }^{4}$.

Choć to Arystotelesa uznaje się za pierwszego teoretyka literatury ${ }^{5}$, w kontekście filologicznym trudno nie wspomnieć o Platonie. Według Hegla jego pisma to jedne $\mathrm{z}$,najpiękniejszych podarunków, jakie los zachował dla nas ze starożytności", je „unikatem w dziejach piśmiennictwa filozoficznego"7.

Platona uważa się za twórcę dialogu. Na polu genologii ukuto

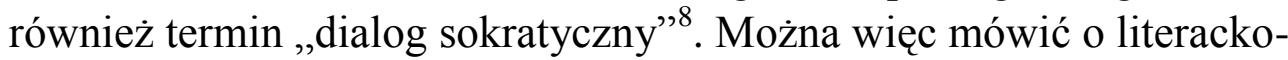
-filozoficznym dualizmie utworów Ateńczyka, przełomowa dla humanistyki refleksja bowiem zostaje zaprezentowana za pomoca fikcji literackiej, jako przedmiot toczącej się rozmowy ${ }^{9}$. Platon nie wyraża swoich poglądów wprost, w formie narracji teoretycznej, lecz poprzez wypowiedzi bohaterów, będące często „zracjonalizowanymi dyskursami”, ,przekazami mitów” lub „opowieściami”.

Z powyższych względów odczytywanie filozoficznych koncepcji Platona zawsze będzie się wiązało $z$ interpretacją jego utworów literackich - barierą między tymi dwoma działaniami badawczymi jest

4 Władysław Tatarkiewicz przedstawia idealizm Platoński w sposób następujący: „[Pojęcia - F.E.C.] muszą [...] mieć swój przedmiot, przedmiotem tym zaś nie mogą być rzeczy, lecz musi nim być jakiś byt inny, którego cechą jest niezmienność" (W. Tatarkiewicz, Historia filozofii, t. 1, Warszawa 1970, s. 75).

Sądzę, że dualistyczną opozycję platońską można odnieść do opozycji Saussure'owskiej; w takim ujęciu system (langue) odpowiada płaszczyźnie idei, zaś wykorzystanie systemu (parole) - planowi przedmiotów. Poszukiwanie dialogu między platonizmem a strukturalizmem nie jest jednak tematem moich rozważań.

5 Zob. H. Podbielski, Wstęp, w: Arystoteles, Poetyka, Wrocław 1983, s. XVIII.

6 G.W.F. Hegel, op.cit., s. 4.

7 W. Tatarkiewicz, op.cit., s. 72.

8 W utworach będących gatunkową realizacją dialogu platońskiego istotną funkcję pełni ironia sokratyczna, niekiedy trudna do zrozumienia, polegająca na zadawaniu pozornie prostych pytań w celu ujawnienia „powierzchowności racji przeciwnika" (zob. M. Głowiński, Ironia sokratyczna [hasło], w: Stownik terminów literackich, red. J. Sławiński, Wrocław 1976, s. 74).

$9 \quad$ Warto zaznaczyć, że ateński filozof i pisarz niezwykle zręcznie posługuje się regułami fikcji literackiej. W Uczcie wykorzystuje zabiegi, po które sięgali później Boccaccio czy twórcy powieści nowożytnej: kompozycję ramową oraz narrację szkatułkową. W przypadku Gorgiasza można mówić o występowaniu skomplikowanych i wielopłaszczyznowych schematów kompozycyjnych (zob. A. Olejarczyk, Dialogi Platona - dzieło otwarte, Wrocław 2001, s. 85-86).

10 M. Głowiński, op.cit., s. 74. 
fikcja literacka, która de iure może oddzielić poglądy filozofa od woli literata. Jak wskazuje Henryk Markiewicz,

[Trudno - F.E.C.] stwierdzić asercję autora wobec zdań ogólnych zawartych w wypowiedziach postaci utworów narracyjnych czy dramatycznych. Można o niej wnioskować na podstawie autorytetu moralnego czy intelektualnego danej postaci lub też przez konfrontację jej wypowiedzi z sensem ideowym całości utworu ${ }^{11}$.

Platon wprowadza do dialogów sokratycznych postać centralną - stanowiącą bezwzględny autorytet moralny i intelektualny. Jest nią Sokrates, porte-parole Platona. Bohater odgrywa rolę swoistego nośnika filozoficznych poglądów autora ${ }^{12}$.

\section{II}

W literackim dorobku Platona znaleźć można interesujący fragment lingwistyczny. Filozofowie starożytnej Grecji obejmowali refleksją problem języka. Próbując uchwycić jego istotę, wyprowadzali różne - niekiedy opozycyjne względem siebie - koncepcje. Platon uczynił je

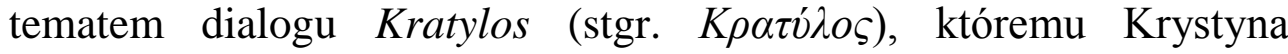
Tuszyńska-Maciejewska nadaje rangę pierwszego europejskiego traktatu językoznawczego ${ }^{13}$. Główną oś tematyczną utworu stanowi problem semiotyczny ${ }^{14}$. W Kratylosie poruszane są również kwestie związane z etymologią i fonologią.

Pojawienie się Sokratesa pełni funkcję otwierającą. Pierwsze słowa dialogu wypowiada Hermogenes: „Czy chcesz, byśmy o zdanie spytali również Sokratesa? Oto on!"15. Przedmiotem przerwanej

11 H. Markiewicz, Gtówne problemy wiedzy o literaturze, Kraków 1976, s. $142-143$.

${ }_{12} \mathrm{Z}$ punktu widzenia filozoficznego jest vice versa - Platon, jako uczeń Sokratesa, inspirował się poglądami swojego mistrza.

13 K. Tuszyńska-Maciejewska, Wstęp, w: Platon, Kratylos, thum. W. Stefański, Wrocław 1990, s. V.

$14, \ldots[. .$. Spory pomiędzy naturalistami i konwencjonalistami były jednymi z najbardziej burzliwych dyskusji, które pojawiły się na gruncie semiotyki” (A. Burzyńska, M.P. Markowski, Teorie literatury XX wieku, Kraków 2007, s. 234).

15 Platon, op.cit., s. 3. W dalszej części artykułu numery stron podano w nawiasie okragłym przy zacytowanym fragmencie dialogu. 
dyskusji jest szeroko rozumiane nazewnictwo. Początkowo adwersarzy jest dwóch: Hermogenes, występujący w roli obrońcy tezy o konwencjonalności związku nazw i przedmiotów, oraz Kratylos, opowiadający się za koncepcją Heraklita, według której nazwy zostały nadane w sposób naturalny.

W celu dokładniejszego wyjaśnienia tej opozycji przytoczę słowa Tadeusza Milewskiego:

Zwolennicy teorii związku naturalnego pojmowali wyrazy jako konieczną reakcję natury ludzkiej na doznawane uczucia i wrażenia zmysłowe, podobnie jak kaszel, wycie i jęk. Natomiast zwolennicy konwencji twierdzili, że nie ma żadnego związku między formą wyrazu a oznaczaną przez niego rzeczą, lecz że to tylko przypadek (týkchē) przydzielił danej rzeczy tę właśnie nazwę, a umowa, konwencja (thésis), zawarta między członkami społeczeństwa, utrwaliła go w tym znaczeniu ${ }^{16}$.

Sokrates chętnie włącza się do rozmowy, lecz już na początku zaznacza swój dystans: ,[...] trudno jest poznać te sprawy. Poddając to wspólnej dyskusji zobaczyć należy, czy jest tak, jak ty mówisz, czy też tak, jak mówi Kratylos" (s. 3). Głos Sokratesa jest głosem obiektywnym, a jednocześnie bardzo krytycznym. Dopełnia „polemiczną triadę", stwarzając okazję do analizy każdego z poglądów osobno.

Hermogenes sądzi, że nie ma nazw stałych, a jedyną prawidłowością W nazewnictwie jest konwencja oraz ogólnie przyjęta zgoda. Sokrates podaje w wątpliwość tę tezę w charakterystyczny dla siebie sposób: poprzez zadawanie kolejnych pytań obnażających luki w sposobie myślenia rozmówcy ${ }^{17}$. Dyskusja już po chwili staje się jednostronna. Młody Hermogenes w odpowiedzi na wszystkie pytania jedynie przytakuje (,sądzę, że są”, ,zgadzam się z tym”, „tak jest” (s. 6)), nie potrafiąc wyprowadzić kontrargumentu wobec przykładów oponenta.

Sokrates zadaje pytanie o pochodzenie nazw. Skoro są one podporządkowane - według odpowiedzi interlokutora - prawom konwencji,

16 T. Milewski, Językoznawstwo, Warszawa 1975, s. 30.

17 Zob. przyp. 8. 
istnieć musi instancja je ukuwająca, jakiś „,słowotwórca” czy „prawodawca" $" 18$.

Sokrates twierdzi, że nazwa jest ,narzędziem nauczającym i rozróżniającym istnienie" (s. 7). Ludzie posługują się mową, lecz nawet wybitny mówca nie jest w stanie kształtować języka - podobnie jak tkacz, który używa czółenka tkackiego, będącego dziełem cieśli. Choć nieustannie posługujemy się nazwami, sam mechanizm symbolizacji pozostaje czymś nadrzędnym i niedostępnym. Istnieć może zatem jakiś niezgłębiony, pozaludzki pierwiastek decydujący o nazewnictwie.

Sokrates w kwiecistej przemowie wyjaśnia pochodzenie wielu wyrazów, będących derywatami (imion i nazw pospolitych), szukając ich źródła. Oto przykład:

Wyraz ,agathón” (to, co dobre) odnosi się z pewnością do czegoś „godnego podziwu" (agastón) spośród całej natury. Skoro byty znajdują się w ruchu, jednym przysługuje prędkość, innym powolność. Nie wszystko jednak to, co posiada prędkość, jest „godne podziwu”, lecz jedynie część tego, to mianowicie, co jest „szybkie” (thoón). Tak pojętemu temu, co „godne podziwu”, przysługuje nazwa „agathón” (to, co dobre) (s. 30).

Długość złożonej etymologicznej dygresji oraz jej jednostajność moga wywołać podejrzenie o ironię. Sokrates ma świadomość dialektycznej przewagi nad mniej doświadczonym dyskutantem. Celowo wprowadza w swój wywód błędy (myląc na przykład fakty z Iliady ${ }^{19}$ ), a $\mathrm{w}$ swojej retoryce zbliża się do sofistów ${ }^{20}$. W pewnym momencie Hermogenes podaje w wątpliwość słowa rozmówcy, mówiąc: „Bardzo

18 „Nie każdy więc człowiek, Hermogenesie, tworzy nazwy, lecz jakiś słowotwórca. Ten zaś, jak się zdaje, jest prawodawcą, i doprawdy rzadki to wśród ludzi typ rzemieślnika" (s. 8, podkr. - F.E.C.).

19 Na pozorną „nieznajomość faktów” z dzieła Homera oraz inne niekonsekwencje myślowe wskazuje autor przypisów, Witold Stefański, zob. Platon, op.cit., s. 11 (przyp. 20).

20 Warto zaznaczyć, że Kratylos jest klasyfikowany jako dialog pedagogiczny, który ma na celu krytykę nauki sofistów. Rozmaite klasyfikacje dialogów Platona przywołuje Kazimierz Leśniak (zob. K. Leśniak, Platon, Warszawa 1993, s. 19-24). 
to śliskie, Sokratesie!" (s. 31), a i sam Sokrates zdaje się nie traktować własnej argumentacji całkowicie poważnie ${ }^{21}$.

Kolejny argument brzmi następująco: nazwy pierwotne występują nie tylko w języku. Odwołując się do semiotycznej triady Charlesa Pierce'a, można powiedzieć, że Sokrates argumentuje naturalność języka możliwością występowania różnych środków przekazu, odnoszących się do tego samego przedmiotu i niosących to samo znacze$\operatorname{nie}^{22}$.

Sokrates twierdzi, że brzmienie niektórych głosek, ze względu na onomatopeiczny charakter, ma wpływ na semantykę wyrazu. Tak oto „«rhō» [w alfabecie greckim: $\rho^{23}$ - F.E.C.] jest jakby narzędziem zdol-

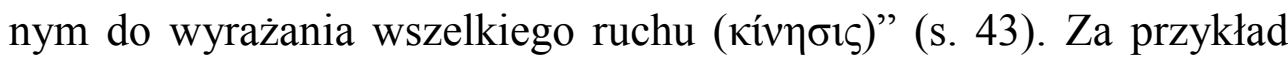
można podać słynne zdanie przypisywane Heraklitowi: Panta rhei

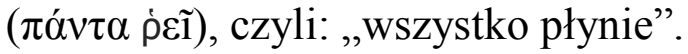

Hermogenes ostatecznie jest zmuszony przyznać bytom oraz ich desygnatom pewną stałośc ${ }^{24}$. Sokrates udowadnia, że nazwy posiadają „«wewnętrzną» istotę"25, którą oddają litery oraz sylaby. W ten sposób prezentuje rozmówcy „«prawidłowość» pierwotnych nazw” (s. 39).

\section{III}

Warto także wspomnieć o nietypowej strukturze kompozycyjnej Kratylosa. Po krótkiej ekspozycji następuje dyskusja między Sokratesem a Hermogenesem, będąca $\mathrm{w}$ istocie rozbudowanym monologiem Sokratesa. Wokół takiego schematu kształtuje się znaczna część dialogu (ok. 80\% treści utworu). Platon wyraźnie opóźnia moment, w którym pozwala dojść do głosu tytułowemu bohaterowi.

21 Niejednoznaczność kategorii estetycznych może wynikać z wąskiego grona potencjalnych odbiorców dialogu, który był kierowany raczej do elitarnego kręgu Akademii aniżeli do szerszej publiczności ateńskiej (K. Tuszyńska-Maciejewska, op.cit., s. V).

22 Zob. A. Burzyńska, M.P. Markowski, op.cit., s. 235.

${ }^{23}$ Co ciekawe, w fizyce symbolem $\rho$ zaznacza się gęstość - a zatem wielkość mającą z ruchem niewiele wspólnego.

${ }^{24}$ K. Tuszyńska-Maciejewska, op.cit., s. IX.

25 Ibidem, s. X. 
Pierwsze słowa wypowiadane przez - milczącego dotąd - Kratylosa można uznać za kluczowe. Gdy zostaje zaproszony przez Hermogenesa do przedstawienia Sokratesowi własnego punktu widzenia, odpowiada: „Cóż to, Hermogenesie, wydaje ci się łatwe tak szybko nauczyć się i nauczyć kogoś jakiejś rzeczy - tym bardziej takiej, która należy do najtrudniejszych?" (s. 45).

Kratylos z pełną powagą ustanawia range problemu - uznaje temat toczącej się dyskusji za rzecz jedną z najtrudniejszych. Następnie, w ramach retorycznego wstępu, komplementuje mądrość Sokratesa. Cytując Homera, wykazuje się niemałą erudycją ${ }^{26}$.

Po chwili dyskusja przybiera znaną, „sokratyczną” formę - Kratylos zaczyna mierzyć się z pytaniami rozmówcy. Ponownie pojawia się problem „prawodawcy” nazw. Myśliciele wspólnie dochodzą do wniosku, że mówienie (a dokładniej: wypowiadanie „w celu nauczania" (s. 45)) jest sztuką, a zatem ma swojego twórcę ${ }^{27}$. Kratylos w przeciwieństwie do Hermogenesa - nie daje się jednak wciąnnać w retoryczną grę Sokratesa. Oto fragment ich rozmowy:

Sok. Wszystkie więc nazwy są prawidłowe?

Kr. O ile tylko są nazwami.

Sok. Cóż więc, wracając do tego, co niedawno powiedziano, czy powiemy, że temu oto Hermogenesowi nie nadano takiego imienia, jeśli nie ma on nic z potomka Hermesa ${ }^{28}$, czy też nadano, lecz nieprawidłowo?

Kr. Według mnie, Sokratesie, nie nadano - wydaje się ono tylko być nadanym - w rzeczywistości jest to imię kogoś innego, kogo natura jest zgodna z tą nazwą (s. 46).

Dyskusja „gęstnieje”; pytania Sokratesa napotykają kontrujące odpowiedzi. Rozmówcy próbują dociec, czy nazwy są prawdziwe

${ }^{26}$ Kratylos przytacza m.in. dwuwersowy fragment Pieśni IX Iliady (644-645): „[...] przychodzi mi ochota powtórzyć ci słowa Achillesa, które ten w «Księdze prób» wypowiada do Ajaksa - mówi on: «Boski Ajaksie, synu Telamona, wodzu armii, zdaje się, żeś wszystko zgodnie z mym sercem powiedział». Tak i twoje wyrocznie, Sokratesie, wydają się być całkiem rozumne" (s. 45).

27 W starożytności sztukę utożsamiano nie $\mathrm{z}$ artyzmem, lecz z rzemiosłem wytwarzaniem rzeczy według reguł (zob. W. Tatarkiewicz, Cywilizacja i kultura, w: idem, Paregra, Warszawa 1978, s. 84).

28 Imię Hermogenes oznacza ,potomek Hermesa”. Wobec tego z punktu widzenia Kratylosa imię Hermogenes nie należy do Hermogenesa, ponieważ de facto go nie nazywa (zob. F. Ademollo, The „Cratylus” of Plato. A commentary, Cambridge 2011, s. 9). 
(mówiąc kolokwialnie: czy rzeczy zostały dobrze ponazywane). Kratylos nie chce uznać, że ,prawodawca” - pierwotny twórca słów mógł się pomylić. Dogmatycznie sądzi, że każda nazwa jest prawdziwa (prawidłowa) ${ }^{29}$ i wchodzi $\mathrm{z}$ innymi $\mathrm{w}$ harmonijną relację. Zgodność $\mathrm{z}$ tak rozumianą prawdą jest według niego cechą konstytutywną nazwy.

Gdy rozmowa schodzi na obszar epistemologii, Sokrates wypowiada następujące słowa: „Zadowólmy się takim stwierdzeniem, że nie z nazw, lecz raczej poprzez rzeczy same należy poznawać i poszukiwać rzeczy. [...] Rozważmy jeszcze to, czy nas te liczne nazwy, sprowadzające do tego samego, nie oszukują" (s. 55).

Według Heraklita (ergo także według jego ucznia, Kratylosa) rzeczywistość można przedstawić za pomoca metafory rzeki -

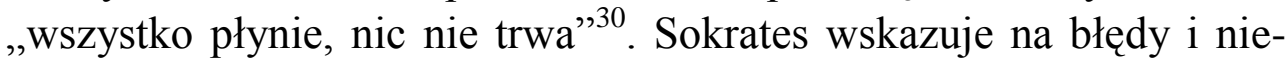
spójności w takim rozumowaniu: skoro wszystko jest w ruchu - skoro pantha rei - poznanie rzeczy jest niemożliwe. Wszak „rzecz sama w sobie, aby być poznana, musi być stała i niezmienna"31.

Sokrates nawiązuje do idealistycznej koncepcji świata - twierdzi, że istnieją byty idealne, jak dobro czy piękno, które cechuje stałość. Prezentuje przed Kratylosem platońską koncepcję ontologiczną ${ }^{32}$, lecz nie rozwija tego wątku. Ma świadomość, że dyskutant nie odejdzie od swoich przekonań. Sokrates, podsumowując rozmowę, wraca do punktu wyjścia:

Czy jest właśnie tak, czy też tak, jak mówią ci z kręgu Heraklita i wielu innych? Obawiam się, że niełatwo to rozstrzygnąć. Nie jest jednak również rozsądne siebie samego, wpatrzonego w nazwy, oraz swą duszę pokrzepiać, wierząc im twórcom. [...] Należy więc mężnie i dzielnie rozważać, i nie przyjmować niczego zbyt pochopnie. [...] Podziel się ze mną, jeśli coś znajdziesz (s. 56-57).

${ }^{29}$ „Powiedzieliśmy, że «prawidłowość» nazwy polega na ukazywaniu, jaka jest rzecz" (s. 45).

30 W. Tatarkiewicz, Historia filozofii, s. 19.

31 K. Tuszyńska-Maciejewska, op.cit., s. XI.

32 Znaną odbiorcy z innych dialogów Platona. 
Polemika zostaje zawieszona - „dialog pozostawia problem otwarty"33. Spór o nazewnictwo, który jest głównym tematem utworu, nie zostaje rozstrzygnięty.

IV

Kratylos to utwór mający wartość naukową z przynajmniej trzech powodów. Po pierwsze, jako dzieło filozoficzne stanowi konfrontację - a zarazem obustronną krytykę - przedsokratejskich poglądów na temat języka oraz interesujący punkt odniesienia do koncepcji samego Platona.

Kratylos - po drugie - jest również dialogiem sokratycznym, stanowiącym dowód na kunszt literacki jego autora. Świadczy o tym nie tylko strona retoryczna utworu, lecz także odwołania intertekstualne (m.in. do wspomnianego już Homera albo innych dialogów) czy niekonwencjonalna struktura kompozycyjna - po nieproporcjonalnie długiej rozmowie Sokratesa i Hermogenesa następuje dynamiczny zwrot i pełna intelektualnego napięcia wymiana zdań z Kratylosem. Platon ostatecznie zawiesza dyskusję, wskazując, że prawda leży pośrodku, a prowadzi do niej droga przez świat idei.

Po trzecie, ze względu na tematykę Kratylosa, utwór ten można uznać za traktat językoznawczy. Dzieło ukazuje, jak rozwinięta była świadomość lingwistyczna Greków, jak subtelne było ich myślenie o języku. Sokrates prezentuje etymologię wielu greckich słów czy imion, a jego semiologiczne rozważania mogą przywoływać na myśl koncepcje XX-wiecznych naukowców ${ }^{34}$.

${ }^{33}$ K. Tuszyńska-Maciejewska, op.cit., s. XIV.

34 Problem nazewnictwa intrygował także późniejszych twórców. Cyprian Norwid wskazuje główny cel, a zarazem przeznaczenie artysty w sposób następujący: „Odpowiednie dać rzeczy słowo!” (C. Norwid, Za wstęp (ogólniki) w: idem, Vade-mecum, oprac. J. Fert, Wrocław 1990, s. 14). Autor Vade-mecum podobnie jak Kratylos - dostrzegał nierozerwalną, naturalną więź łącząca nazwę oraz istotę rzeczy. Jej odnalezienie zbliża pisarza do zgłębienia mistycznych sfer ludzkiej duszy i odkrycia prawdy estetycznej. 


\section{Bibliografia}

\section{Literatura podmiotu}

Platon, Kratylos, tłum. W. Stefański, Wrocław 1990.

\section{Literatura przedmiotu}

Ademollo F., The „Cratylus” of Plato. A commentary, Cambridge 2011.

Arystoteles, Poetyka, Wrocław 1983.

Burzyńska A., Markowski M.P., Teorie literatury XX wieku, Kraków 2007.

Głowiński M., Ironia sokratyczna [hasło], w: Stownik terminów literackich, red. J. Sławiński, Wrocław 1976, s. 74.

Hegel G.W.F., Wyktady z historii filozofii, thum. Ś.F. Nowicki, t. 2, Warszawa 1996.

Król Z., Platon i podstawy matematyki wspótczesnej. Pojęcie liczby u Platona, Nowa Wieś 2005.

Leśniak K., Platon, Warszawa 1993.

Markiewicz H., Gtówne problemy wiedzy o literaturze, Kraków 1976.

Milewski T., Językoznawstwo, Warszawa 1975.

Norwid C., Vade-mecum, oprac. J. Fert, Wrocław 1990.

Olejarczyk A., Dialogi Platona - dzieło otwarte, Wrocław 2001.

Tatarkiewicz W., Cywilizacja i kultura, w: W. Tatarkiewicz, Paregra, Warszawa 1978, s. 74-92.

Tatarkiewicz W., Historia filozofii, t. 1, Warszawa 1970.

Voegelin E., Platon, thum. A. Legutko-Dybowska, Warszawa 2009. 


\title{
Between the nature and the convention. The problem of naming in the socratic dialogue
}

\author{
SUMMARY
}

The main goal of the article is to analyze the problematic aspects of the socratic dialogue Cratylus by Plato. The literary work concerns the problem of naming. It presents the discussion between three characters: Hermogenes, Cratylus and Socrates. Plato confronts two views on the language: the first treats the connection between a name and a subject as a natural connection; the second - as a conventional connection.

Analyzing the dialogue, the author of the article takes three points of view: the philosophical perspective, the literary perspective and the linguistic perspective.

Key words: name, naming, nature, convention, Cratylus. 
O Autorze:

Filip E. Czaja (ur. 1995) - student filologii polskiej Uniwersytetu Wrocławskiego. Zainteresowany punktem wspólnym literaturoznawstwa, psychologii i filozofii - w szczególności translatologia, teoria narracji i jezykiem ezopowym.

E-mail: filipczaja95egmail.com 